\title{
Evaluation of The Patulin Content of Certain Non- Alcoholic Beverages (Gnamankoudji, Bissap And Tomi) Sold on The Streets of Daloa (Côte d'Ivoire)
}

\author{
Ehouman Ano Guy Serge, Yao N'zué Benjamin, Kpata-Konan Nazo Edith, Traore Karim Sory and \\ Tano Kablan
}

\begin{abstract}
This study was conducted to ascertain the Sanitary state of beverages (Gnamankoudji, Bissap and Tomi) sold in the streets of Daloa (Côte d'Ivoire). To conduct the study, a survey was carried out to diagnose the different nonalcoholic artisanal drinks sold in the town of Daloa. The diagnosis revealed that $87.5 \%$ of consumers buy the drinks from the vendors while $12.5 \%$ produce them themselves. These drinks are consumed mainly by $\mathbf{7 7 \%}$ of young people $(<30$ years old), mostly pupils and students. Furthermore, $83.5 \%$ of the respondents have no knowledge of chemical contamination of the beverages they consume and various ailments have been reported by consumers. Toxicological analyses carried out on these three (3) beverages revealed that they present a risk to the health of the consumer. This is because the level of contamination of these beverages is three (3) to five (5) times higher than the European recommendations on the maximum tolerable level of PAT $\left(50 \mu \mathrm{g} . \mathrm{L}^{-1}\right)$ in fruit juices and derived beverages.
\end{abstract}

Index Terms - patulin, Bissap, gnamakoudji, Tomi, Daloa, Côte d'Ivoire.

\section{INTRODUCTION}

Non-alcoholic beverages are among the emerging foodstuffs of recent decades. They are much appreciated and consumed in abundance by all age groups and practically at all celebratory ceremonies (weddings, baptisms, birthdays, etc.) in many countries of the subregion [3]. Following the example of these countries, in Côte d'Ivoire, these nonalcoholic artisanal drinks are appreciated for their energy intake (Kcal), their richness in vitamins (especially vitamin C) and trace elements [11]. In Daloa, they are sold on roadsides, in markets and in densely populated areas such as schools and bus stations [13]. Because of their affordable cost, these soft drinks are an important part of the population's eating habits. However, the quality of these beverages raises concerns among consumers. Indeed, the raw materials used for the production of these drinks are in most cases subject to chemical contamination. Thus, these

Published on July 22, 2020.

Ehouman Ano Guy Serge, Université Jean Lorougnon Guédé, Côte D'Ivoire.

Yao N'zué Benjamin, Université Jean Lorougnon Guédé, Côte D'Ivoire. (corresponding e-mail: nzuebenjamin ${ }^{\circledR}$ yahoo.fr)

Kpata-Konan Nazo Edith, Université Jean Lorougnon Guédé, Côte D'Ivoire.

Traore Karim Sory, Université Nangui Abrogoua, Côte D’Ivoire.

Tano Kablan, Université Nangui Abrogoua, Côte D’Ivoire. non-alcoholic beverages, considered as a source of energy, are transformed over the years into a vector of toxic substances. These chemical contaminant patches include mycotoxins, which are secondary metabolites produced by fungi (moulds) and found in a wide variety of plant-based foods. Controlling the health risks associated with these chemical pollutants is considered a major challenge for the consumer because of their harmful effects on human health. Numerous toxicological studies have revealed the presence of many mycotoxins in foods with levels exceeding the toxicological standards in force [1], [12], [10]. Several disease outbreaks have been attributed to street foods such as artisanal beverages around the world [4], [14]. This unfortunate finding is now a source of concern for consumers because the food risks associated with the presence of these chemical pollutants (mycotoxins) are at the heart of health and wellness issues. For these reasons, European standards recommend maximum levels for certain mycotoxins, including patulin, in raw materials and foodstuffs in order to protect the consumer [1], [14]. The purpose of this study is to ascertain the health status of beverages (Gnamankoudji, Bissap and Tomi) sold in the streets of Daloa (Côte d'Ivoire) in order to participate in raising awareness among consumers and public authorities on this important public health issue.

\section{MATERIALS AND METHODS}

\section{A. Material}

\section{Study matrices}

For the search for patulin (mycotoxin), the various analyses were carried out on soft drinks (Bissap, Gnamankoudji and Tomi) sold in several districts of the city of Daloa (Fig. 1). The Bissap drink is made from the flowers of Hisbiscus sabdarifa, the "Gnamankoudji" drink is prepared from extracts of rhizomes of Zingiber officinale, the "Tomi" drink is obtained from a mixture of fruit of Tamarindus indica.

\section{Solvents and Laboratory Equipment}

A patulin standard with a concentration of $25 \mu \mathrm{g} \cdot \mathrm{mL}^{-1}$ (stored at $8{ }^{\circ} \mathrm{C}$ protected from light) was contacted with 5 $\mathrm{mL}$ of acetonitrile supplied by VWR CHEMICALS (France). Solvents such as acetic acid, sodium carbonate and anhydrous "Prolabo" grade sodium acetate were supplied by Sigma Aldrich (France). The water used in the handling is distilled and de-ionized in the Laboratory. Stirring was carried out on an IKA KS 130 basic stirring table. 
Evaporation was carried out by a rotary evaporator (rotavapor-215). The filters used were whatman paper No. 113 with a porosity of $45 \mu \mathrm{m}$ supplied by R-Biopharm (Germany). A SHIMADZU (Japan) high-performance liquid chromatography (HPLC) line was used for the quantification of patulin.

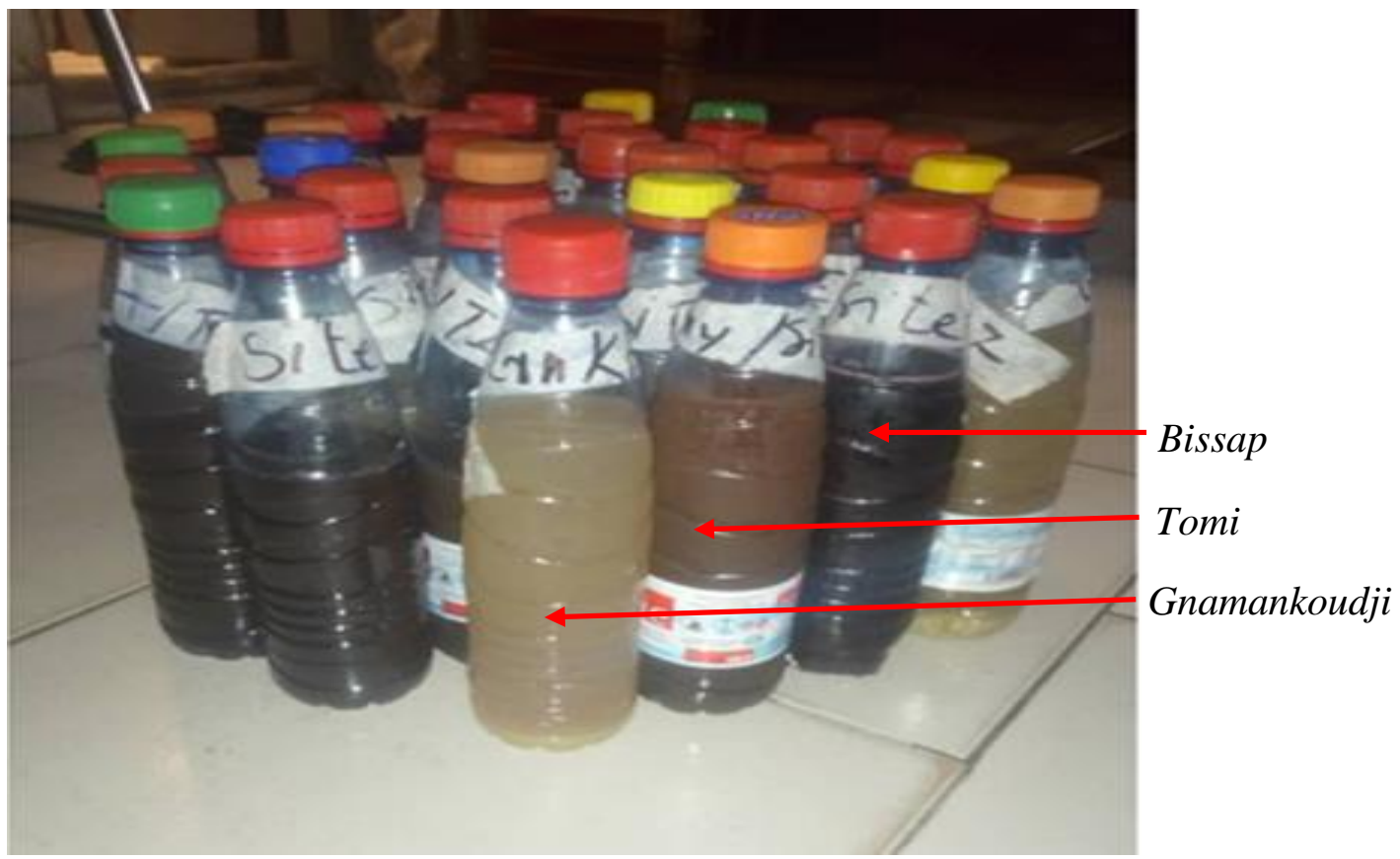

Fig. 1. Some non-alcoholic drinks sold on the streets of Daloa (Côte d'Ivoire).

\section{B. Methods}

\section{Food Survey}

In the present study, the food survey was carried out with the aim of gaining a better knowledge of the dietary habits regarding the consumption of non-alcoholic beverages by the population of the town of Daloa. In order to achieve this objective, the survey method chosen is the "food survey by interview (interrogation)". Survey sheets have been developed for this purpose.

\subsection{Framework of the Investigation}

The survey focused on the sale and consumption of nonalcoholic beverages (Bissap, Gnamankoudji and Tomi) by the population of the city of Daloa. It was conducted exclusively in the town of Daloa (Côte d'Ivoire), in the districts of Abattoir, Garage, Kennedy, Labia, Lobia Manioc, Tazibouo and Texas. It took place in the months of November-December 2018. At this time of the year (dry season), the consumption of these drinks by the populations becomes important because of the very high heat during this period of the year.

\subsection{Practical conduct of the investigation}

The investigative technique used is "Food History by Interrogation". This mode of investigation has made it possible to question a large number of subjects (sellers and consumers) from several age categories. During this survey, the subjects had not been warned in advance by the investigator. They were approached and they found the study to be well-founded and they made themselves available to the interviewer by answering the various questions mentioned on the various cards. The survey was carried out on subjects (samples) selected randomly, on a representative sample of the Daloa population. At the end of this survey, 200 people were interviewed, including 175 consumers and 25 vendors.

\section{Sample Collection}

The sampling plan adopted is that of Directive 2005/5/CE applied to fruit juices and/or drinks. That Directive lays down the sampling method and the methods of analysis for the official control of the levels of Ochratoxin A and certain mycotoxins in certain foodstuffs. The beverages (Bissap, Gnamankoudji and Tomi) which were analysed were taken from different sites (8) in the town of Daloa. A total of 30 samples were collected (10 samples per type of beverage) with randomly selected vendors in the different neighbourhoods that were targeted for this study. The different samples collected are listed in Table I. These samples were labelled (site, date and time of collection) and placed in sterile bottles of approximately $250 \mathrm{~mL}$. These bottles were covered with aluminum foil and sealed to limit oxidation phenomena. These bottles were placed in a cooler containing ice. The samples were then stored in a refrigerator at $4{ }^{\circ} \mathrm{C}$ before being analyzed in the laboratory.

3. Analytical Methods for the Determination of Patulin in Beverages

Patulin (PAT) was extracted with ethyl acetate and then purified by extraction with sodium carbonate. After evaporation of the ethyl acetate, PAT is determined by reverse phase liquid chromatography using a $\mathrm{C} 18$ column and a UV detector.

\subsection{Preparation of Analytical Solutions}

\subsubsection{Preparation of $\mathrm{pH} 4$ buffer solution}

The buffer solution consists of $16.4 \mathrm{~mL}$ acetic acid solution with a concentration of $0.2 \mathrm{~mol}$.

$\mathrm{L}^{-1}$ and $3.6 \mathrm{~mL}$ sodium acetate solution with a 
concentration of $0.2 \mathrm{~mol} . \mathrm{L}^{-1}$. The buffer solution consists of $16.4 \mathrm{~mL}$ acetic acid solution with a concentration of 0.2 mol. $\mathrm{L}^{-1}$ and $3.6 \mathrm{~mL}$ sodium acetate solution with a concentration of $0.2 \mathrm{~mol} . \mathrm{L}^{-1}$. The buffer solution is used for the determination of the $\mathrm{pH}$ value of the sample. The $\mathrm{pH}$ value of the buffer solution is 4 .

\subsubsection{Preparation of the sodium carbonate solution}

A quantity of $1.4 \mathrm{~g}$ of sodium carbonate was removed and placed in a $100 \mathrm{~mL}$ volumetric flask. This flask was made up to the mark with bi-distilled water, stirred well and homogenized.

\subsubsection{Preparation of the patulin solution}

Take $300 \mu \mathrm{L}$ of the patulin standard to which $200 \mu \mathrm{L}$ of acetonitrile has been added. The mixture was evaporated to dryness and the evaporation residue was taken up by $2500 \mu \mathrm{L}$ of the buffer solution. The solution in one vial was wrapped in aluminum foil and stored in a refrigerator at $5^{\circ} \mathrm{C}$. This stock solution was used in the various tests for the calibration of the assay method.

\subsection{Extraction and purification of patulin in beverages}

In this study, patulin extraction was performed using the liquid-liquid extraction (LLE) protocol. A $5 \mathrm{~mL}$ sample of initially diluted beverage concentrate was extracted with 3 successive $5 \mathrm{~mL}$ portions of ethyl acetate by vigorously shaking for 1 minute using a vortex shaker. The organic phase was extracted with $2 \mathrm{~mL}$ of aqueous sodium carbonate solution $(1.4 \mathrm{~g} / 100 \mathrm{~mL})$ by strong agitation. Then the aqueous phase was separated and immediately extracted with $5 \mathrm{~mL}$ ethyl acetate by stirring for one minute. The organic phase was dried on $2 \mathrm{~g}$ anhydrous sodium sulfate and filtered through a Whattman No. 4 paper filter. Subsequently, 5 drops of acetic acid were added to neutralize the carbonate. The extract was evaporated just in a water bath at $40{ }^{\circ} \mathrm{C}$ using a rotary evaporator (Rotavapor). The residue was dissolved in $500 \mu \mathrm{L}$ of the buffer solution at $\mathrm{pH}$ 4. The sample is filtered through a PTFE disc filter with a porosity of $0.45 \mu \mathrm{m}$ and the final solution is collected in a vial and injected into the column.

\subsection{Detection and quantification of patulin in beverages}

\subsubsection{Analytical detection of patulin (PAT)}

The detection of patulin in beverages and standards was performed by a SCHIMADZU branded HPLC chain under the following analytical conditions:

- stationary phase: LICHROSORB 100RP-18 column (5 $\mu \mathrm{m}, 250 \times 4 \mathrm{~mm}$ ID) in reverse phase.

- mobile phase: it consists of an acetonitrile-water mixture (10\%: $90 \%, \mathrm{v} / \mathrm{v})$.

- elution mode: isocratic.

- injection volume: $20 \mu \mathrm{L}$.

- wavelength: $276 \mathrm{~nm}$.

- flow rate: $1 \mathrm{~mL} . \mathrm{min}-1$.

- analysis time: $10 \mathrm{~min}$.

- oven temperature: $40{ }^{\circ} \mathrm{C}$.

\subsubsection{Quantification of patulin}

The $\mathrm{C} 0$ concentration of patulin in the final solution was determined using the calibration curve of concentration versus peak area. The $\mathrm{C}$ concentration of PAT in the beverages was determined from the following formula:

$$
\mathrm{C}\left(\mu \mathrm{g} . \mathrm{L}^{-1}\right)=\frac{1000 * V f * C_{0}}{V}
$$

$\mathrm{C}_{0}$ : concentration of PAT in the final solution $\left(\mu \mathrm{g} \cdot \mathrm{mL}^{-1}\right)$.

Vf: total volume of final solution $(\mathrm{mL})$.

$\mathrm{V}$ : volume of fruit juice taken for extraction $(\mathrm{mL})$.

The $\mathrm{C}_{0}$ concentration was determined as follows:

$$
\mathrm{C}_{0}=\frac{A_{T}}{A_{E}} * \mathrm{C}_{\mathrm{E}}
$$

$\mathrm{A}_{\mathrm{T}}$ : peak area of the test sample.

$\mathrm{A}_{\mathrm{E}}$ : peak area of the standard.

$\mathrm{C}_{\mathrm{E}}$ : concentration of standard $\left(\mu \mathrm{g} \cdot \mathrm{mL}^{-1}\right)$.

Then from the calculation of $\mathrm{C}_{0}$ the concentration $\mathrm{C}$ of PAT in the drink is determined using equation (1).

The calibration curve shows the detector response at the HPLC chain as a function of the peak area which allows the actual concentration of the eluate to be calculated through the Co concentration given by the equation on the indicated line.

\section{Statistical analysis of data}

To evaluate the data, descriptive statistics and statistical analyses were performed using the XLSTAT statistical software version 7.5 and the EXCEL 2010 spreadsheet. This allowed us to calculate the means and standard deviations in order to compare the samples. Indeed, for the k-sample comparison tests, we used the Chi-square test with a significance level at the $5 \%$ threshold to show the relationship between the different parameters analyzed. For the soft drink analysis data, a Kruskal-wallis test was also used for comparison tests of $\mathrm{k}$ independent samples with a $5 \%$ significance level. If the P-value is $>\alpha$ (Alpha) $=0.05$ : the difference between the samples is not significant. But if the determined P-value is $<\alpha($ Alpha $)=0.05$ : the difference between the samples is significant.

\section{RESULTS}

\section{A. Food survey}

\section{Characteristics of consumers of soft drinks}

The food survey revealed that non-alcoholic beverages (Gnamankoudji, Bissap and Tomi) are consumed by both men and women. In fact, of the 200 subjects investigated, $40 \%$ were men and $60 \%$ were women. These artisanal drinks are popular among all age groups (Table I).

TABLE I: DESCRIPTION OF THE POPULATION STUDIED

\begin{tabular}{|c|c|c|}
\hline \multicolumn{2}{|c|}{ Characteristics } & Percentage \\
\hline \multirow{2}{*}{$\begin{array}{c}\text { Population } \\
\text { surveyed }\end{array}$} & Men & 40 \\
\cline { 2 - 3 } & Women & 60 \\
\hline \multirow{4}{*}{ Age groups } & $<10$ ans & 40 \\
\cline { 2 - 3 } & $10-30$ ans & 37 \\
\cline { 2 - 3 } & $30-40$ ans & 23 \\
\hline
\end{tabular}

\section{Distribution of non-alcoholic beverage consumption in} Daloa (Côte d'Ivoire)

In the town of Daloa soft drinks are consumed by the population. Among these drinks, "Gnamankoudji" and "Bissap" are the most consumed by the population of Daloa and therefore the most sold in the city. Tomi is little consumed (Fig. 2). 


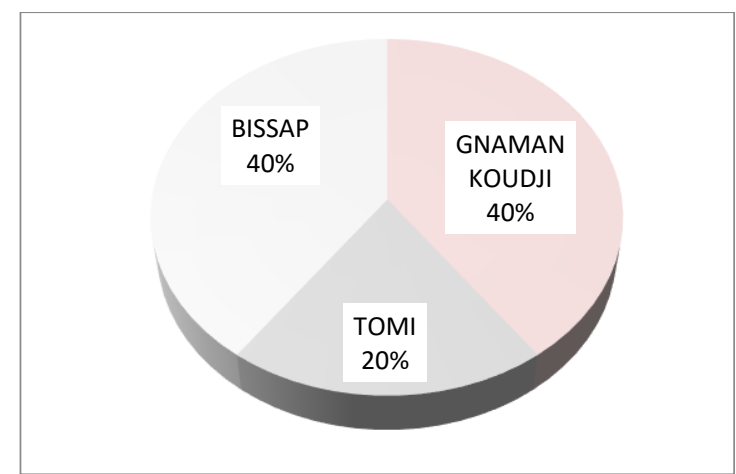

Fig. 2. Distribution of non-alcoholic beverages consumed in Daloa (Côte d'Ivoire.

\section{State of patulin contamination of Gnamankoudji}

Table II shows the levels of PAT detected in Gnamankoudji. Analysis of samples from Gnamankoudji revealed that samples from 4 sites are heavily contaminated with patulin. The amounts of PAT found in Gnamankoudji beverage samples ranged from 5.414 to $683.545 \mu \mathrm{g} . \mathrm{kg}^{-1}$ with a mean of $157.172 \mu \mathrm{g} \cdot \mathrm{kg}^{-1}$. At two (02) sites, concentrations were undetectable by the analysis performed and at sites 1 and 7 the levels found are below the limit of quantification $\left(<\mathrm{LQ}=4.63 \mu \mathrm{g} . \mathrm{L}^{-1}\right)$.

\section{TABLE II: PATULIN CONTENTS DETECTED IN GNAMANKOUDJI}

\begin{tabular}{|c|c|c|}
\hline $\begin{array}{c}\text { Sampling } \\
\text { sites }\end{array}$ & Drink & Patulin content $\left(\mu \mathrm{g} \cdot \mathrm{L}^{-1}\right)$ \\
\hline SITE 1 & \multirow{10}{*}{ GNAMANKOUDJI } & $<\mathrm{LQ}$ \\
\hline SITE 2 & & 683.545 \\
\hline SITE 3 (a) & & ND \\
\hline SITE 3 (b) & & ND \\
\hline SITE 4 & & 5.414 \\
\hline SITE 5 (a) & & 51.430 \\
\hline SITE 5(b) & & 10.676 \\
\hline SITE 6 & & 34.797 \\
\hline SITE 7 & & $<\mathrm{LQ}$ \\
\hline SITE 8 & & $\mathrm{ND}$ \\
\hline & Average & 157.172 \\
\hline & Standard deviation & 263.710 \\
\hline & Maximum content & 683.545 \\
\hline & Minimum content & 5.414 \\
\hline & $\begin{array}{l}\text { Rate of contaminated } \\
\text { samples }\end{array}$ & $50 \%$ \\
\hline
\end{tabular}

ND: Not Detected; < LQ: below the limit of quantification; LQ $=4.63 \mu \mathrm{g} . \mathrm{L}^{-1}$ SITES 3 and 5: each have two sampling points ( $a$ and $b$ ).

\section{Patulin contamination status of Bissap}

Analyses performed on the Bissap samples (Table III) revealed that Bissap is contaminated with PAT. Indeed, out of the ten (10) samples analyzed, seven (07) samples contained levels ranging from 34.037 to $716.102 \mu \mathrm{g} . \mathrm{kg}-1$ with a mean level of $203.384 \mu \mathrm{g} . \mathrm{kg}-1$. The results also show that three (03) sites, namely sites ( $3 \mathrm{~b}, 7$ and 8 ) have patulin levels below the limit of detection $(<\mathrm{LD}=1.38 \mu \mathrm{g} . \mathrm{L}-1)$. Also, the contamination rate of Bissap beverages is $70 \%$ of the samples analyzed.

\section{State of contamination of Tomi by patulin}

The analysis of the Tomi samples shows that out of the ten (10) samples, seven (7) show a high level of contamination ranging from 13.061 to $1175.960 \mu \mathrm{g} \cdot \mathrm{kg}^{-1}$ (Table 4) with an average PAT content of $157.172 \mu \mathrm{g} \cdot \mathrm{kg}^{-1}$, representing $70 \%$ of all Tomi samples analysed. Three (IV) samples, namely (3d, 6 and 7), had PAT levels below the limit of detection $\left(<\mathrm{LD}=1.38 \mu \mathrm{g} . \mathrm{L}^{-1}\right)$.
TABLE III: PATULIN CONTENTS DETECTED IN BISSAP

\begin{tabular}{|c|c|c|}
\hline $\begin{array}{l}\text { Sampling } \\
\text { sites }\end{array}$ & Drink & Patulin content $\left(\mu \mathrm{g} \cdot \mathrm{L}^{-1}\right)$ \\
\hline SITE 1 & \multirow{10}{*}{ BISSAP } & 34.037 \\
\hline SITE 3 (a) & & 285.391 \\
\hline SITE 3 (b) & & ND \\
\hline SITE 4 & & 36.338 \\
\hline SITE 5 (a) & & 166.380 \\
\hline SITE 5 (b) & & 37.801 \\
\hline SITE 6 & & 716.102 \\
\hline SITE 7 & & ND \\
\hline SITE 8 & & 147.643 \\
\hline SITE 8 & & ND \\
\hline & Average & 203.384 \\
\hline & Standard deviation & 226.173 \\
\hline & Maximum content & 716.102 \\
\hline & Minimum content & 34.037 \\
\hline & $\begin{array}{l}\text { Rate of contaminated } \\
\text { samples }\end{array}$ & $70 \%$ \\
\hline
\end{tabular}

ND: Not Detected; <LQ: below the limit of quantification. $\mathrm{LQ}=4.63 \mu \mathrm{g} . \mathrm{L}^{-1}$. SITES 3 and 5: each have two sampling points ( $a$ and $b$ ).

TABLE IV: PATULIN CONTENTS DETECTED IN TOMI

\begin{tabular}{|c|c|c|}
\hline $\begin{array}{c}\text { Sampling } \\
\text { sites }\end{array}$ & Drink & Patulin content $\left(\mu \mathrm{g} \cdot \mathrm{L}^{-1}\right)$ \\
\hline SITE 3(a) & \multirow{10}{*}{ TOMI } & 13.061 \\
\hline SITE 3 (b) & & 64.169 \\
\hline SITE 3 C & & 1175.960 \\
\hline SITE 3 (d) & & ND \\
\hline SITE 4 (a) & & 229.865 \\
\hline SITE 4 (b) & & 582.617 \\
\hline SITE 5 & & 21.029 \\
\hline SITE 6 & & ND \\
\hline SITE 7 & & ND \\
\hline SITE 8 & & 14.940 \\
\hline & Average & 283.503 \\
\hline & Standard deviation & 381.576 \\
\hline & Maximum content & 1175.960 \\
\hline & Minimum content & 13.061 \\
\hline & $\begin{array}{l}\text { Rate of contaminated } \\
\text { samples }\end{array}$ & $70 \%$ \\
\hline
\end{tabular}

ND: Not detected ; < LQ: below the limit of quantitation. $\mathrm{LQ}=4.63 \mu \mathrm{g} . \mathrm{L}^{-1}$ SITE 3: have four sampling points (a, b, c and d).

SITE 4: have two sampling points ( $a$ and $b$ ).

6. Comparative study between patulin content in beverages and the permitted standard

Figure 3 shows the comparison of the average patulin content in beverages and the standard (MPL). The average levels detected in these beverages are much higher than the MPL. These levels are not in compliance with the regulation that sets the maximum limits of $50 \mu \mathrm{g} \cdot \mathrm{kg}^{-1}$ PAT in fruit juices and derived beverages according to CE Regulation No. $1881 / 2006$ of 19/12/2006.

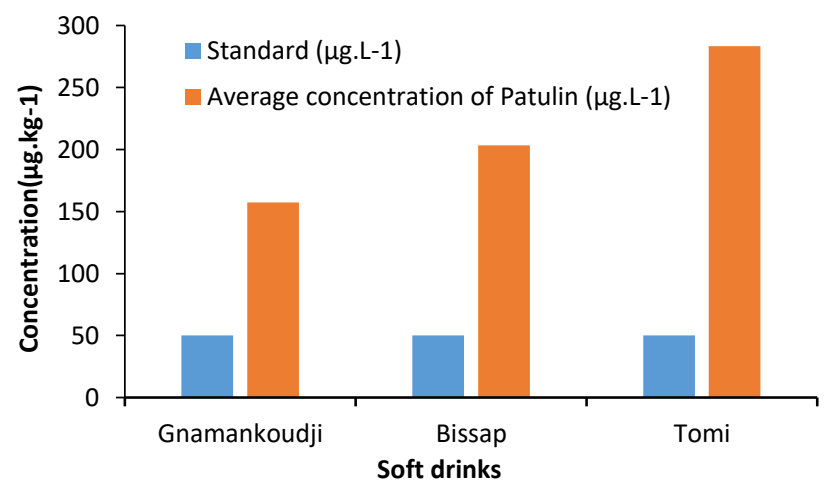

Fig. 3. Comparison of average patulin content in beverages and maximum permitted level (EC 2006). 


\section{DISCUSSION}

Handcrafted drinks are widely consumed by the people of Daloa. The main non-alcoholic artisanal drinks identified by their importance were: Bissap, Gnamankoudji and Tomi. Drabo et al. [9] inventoried the same types of street drinks in Bobo-Dioulasso (Burkina Faso) but in a different order of importance from that of Daloa. This difference could be due to the local availability of drink types and certain eating habits among different people. The consumption of nonalcoholic artisanal drinks is $77 \%$ dominated by the youngest $(<30$ years old). The vast majority of this age group are pupils and students. Their lack of consistent income may be one of the reasons for their preference for these beverages, which are accessible to all. This was revealed in the work of Bendech et al. [5] who noted that $89 \%$ of low-income people under 30 years of age consume at least one street food item on a daily basis. Moreover, their consumption is linked to their professional status. These results corroborate those of Danel [8] who also established a strong link between the consumption of street foods and the professional status of the populations of Ouagadougou (Burkina Faso). Since patulin is a toxic metabolite produced by several fungal species, mainly Penicillium expansum, it is now a major concern for beverage producers and consumers. The first step in the production of Patulin, as for many mycotoxins, is the colonisation of the host by the producing fungus, which occurs mainly during the storage of the raw material, in response to several favourable extrinsic factors (temperature, humidity, etc.). Indeed, the appearance of toxin is only the consequence of the development of the fungus inside the raw material, as Tannons et al. [16] noted in their various works on the contamination of apples by patulin, thus according to Tannons et al. [16] there is no contamination of apples by patulin without the appearance of brown lesions. The results obtained in this study showed a high level of contamination of Tomi, Gnamankoudji and Bissap drinks by PAT. These results are in line with the studies carried out by Tannons et al. [16] on apples and derived products, this contamination amounted to more than $60 \%$ of the total production. Thus. proving that patulin can be found in all products resulting from the processing of raw materials. However, the level of contamination of Tomi (70\%), Bissap (70\%), and Gnamankoudji (50\%) drinks can be explained on the one hand by the method of conservation of the raw material (flower, fruit and rhizome) used for the manufacture of these drinks, This finding was also made in the work of Agassounon et al. [2] and those of Ndiaye et al. [15] on the "Bissap", which stressed that molds develop in beverages during storage of raw materials. Also, the only heat treatment at the beginning of the process could not guarantee other sources of contamination in the process. The conservation is one of the factors that influence the growth of moulds and therefore the production of mycotoxins. These raw materials during the preservation phase go through different stages of washing and drying at room temperature which lasts one to several days. Thus. the humidity and temperature being ideal in these conditions, favour the growth of fungi and the massive production of mycotoxins. On the other hand, the intrinsic composition of the different raw materials (anti-microbial character), the environment for the sale of raw materials (flower, fruit and rhizome) not controlled as highlighted by some authors (Kouassi et al. 2018) and the presence of an external protective envelope in the rhizomes used for the manufacture of Gnamankoudji helps to explain the low proportion of contamination (50\%) of the Gnamankoudji drink, contrary to the latter, the Hibiscus sabdariffa flowers for Bissap and the tamarind fruits (Tamarindus indica) for "Tomi" are sold without an external protective envelope which explains the high contamination rates $(70 \%)$. Several works of the authors such as Tannons [16] which confirms a natural sporadic occurrence of PAT in apple juices and apple products. The present study allowed us to show that, like apple juices, artisanal non-alcoholic beverages have fairly high levels of contamination with average levels of PAT contamination exceeding $200 \mu \mathrm{g} . \mathrm{L}^{-1}$ for Tomi, Bissap and levels exceeding $150 \mu \mathrm{g} . \mathrm{L}^{-1}$ for Gnamankoudji beverage. These average levels are higher than the regulation that sets the maximum limits at $50 \mu \mathrm{g} . \mathrm{kg}^{-1}$ PAT in fruit juices and derived beverages according to EC Regulation No. 1881 /2006 of 19/12/2006.

\section{CONCLUSION}

Our study revealed that drinks are consumed a lot by the Daloa population (87.5\% of respondents). The consuming population is dominated by the youngest $(<30$ years old). Also, 167 people $(83.5 \%$ ) have no knowledge of chemical contamination of the soft drinks they consume. Thus, for a question of safety of the food we consume, the "Bissap", "Gnamankoudji" and "Tomi" sold in the city of Daloa have been the subject of a toxicological study to assess the level of contamination of these different drinks by patulin. The analysed samples gave PAT levels with contamination levels three (3) to five (5) times higher than the European recommendations on maximum tolerable levels of PAT in fruit juices and derived beverages. As a result, the consumption of these non-alcoholic beverages presents a greater health risk to the consumer. Thus, the competent authorities must provide information and raise awareness to create a greater awareness of the health risks incurred by consumers. The levels of PAT in beverages must challenge us to put in place a prevention strategy to reduce the extent and consequences of the contamination of these beverages by patulin in Côte d'Ivoire. It would be important to set up regulations for artisanal drinks to limit the risks of contamination, to make an inventory of possible contamination of other mycotoxins (ochratoxin, fumonisins and aflatoxin) in other foodstuffs and products derived from fruits, such as traditional juices, traditional alcoholic drinks (tchapalo) and submit these data to the FAO/WHO Coordinating Committee for Africa for a health assessment of exposure of African populations to mycotoxins.

\section{REFERENCES}

[1] AFSSA 2006. Évaluation des risques liés à la présence de mycotoxines dans les chaînes alimentaires humaine et animale. Rapport synthétique, $82 \mathrm{p}$.

[2] Agassounon, D., Bada, F., Ahanhanzo, C., Adisso, S.A., Toukourou F. \& De souza C. 2011. Effets des huiles essentielles sur les qualités 
hygiéniques et organoleptiques de la boisson "Bissap". Review of Industrial Microbiology Sanitary and Environnemental 5(1):1-23.

[3] Andrieu, E., Caillavet F., Huissier, A., Momic, M. \& Régnier, F. 2006. L'alimentation comme dimension spécifique de la pauvreté Approches croisées de la consommation alimentaire des ménages défavorisés. Les Travaux de l'Observatoire, Deuxième partie, Cahier 1: 247-278.

[4] Baba, L., Bokossa, Y., Baba, F., Ahissou, H., Adeoti, Z., Yehouenou, B., Mamadou, A., Toukourou, F. \& Sanni, A. 2006. Étude des possibilités de contamination des aliments de rues au Benin : cas de la ville de Cotonou. Journal de la Recherche Scientifique de Université de Lomé (Togo), 8(2): 149-156.

[5] Bendech, M., Chauliac, M., Gerbouin, P., Kante, N. \& Malvy, D. 2000. Les enjeux de la consommation alimentaire en milieu urbain à Bamako. Santé publique 12(1):45-63.

[6] CE 2005. Directive 2005/5/CE de la commission du 26 Janvier 2005 modifiant la directive : 2002/26/CE en ce qui concerne les modes de prélèvement d'échantillons et les méthodes d'analyse pour le contrôle officiel des teneurs en Ochratoxine A de certaines denrées alimentaires.

[7] CE 2006. Règlementation CE $N^{\circ} 1881 / 2006$ de la 19/12/2006 Portante règlementation des teneurs maximales en patuline dans les jus de fruits concentrés (boissons) fixé à $50 \mu \mathrm{g} / \mathrm{kg}$.

[8] Danel, P. 2005. Etude de la consommation alimentaire à Ouagadougou, Burkina Faso typologie des régimes. Mémoire de fin d'étude en Nutrition Humaine (Département Sociétés et Santé), Institut National Agronomique Paris-Grignon, Paris, France, $80 \mathrm{p}$.

[9] Drabo, K.M., Pare, Toe L., Savadogo, L.G.B., Tarnagda, Z., Zeba, A.N., Zongo, I., Rouamba, J., Toe, A., Ouédraogo, D. \& Ouédraogo, J.B. 2009. Caractéristiques de l'alimentation de rue dans la ville de Bobo-Dioulasso, Burkina Faso. Bulletin de la Société de Pathologie Exotique 102(1): 36-40.

[10] Ehouman, A., Yao, B., Hampoh, A., Fofana, A., Traore, K. \& Tano, K. (2017). Mycotoxins in food: Evaluation of Aflatoxin B1 and Ochratoxin $\mathrm{A}$ in a few foodstuffs in Côte d'Ivoire. International Journal of Current Research in Biosciences and Plant Biology 4(11):1-8.

[11] INRA 2007. Les fruits et légumes dans l'alimentation : enjeux et déterminants de la consommation. Synthèse du rapport d'expertise réalisé par l'INRA à la demande du Ministère de l'Agriculture et de la Pêche. 88 P. disponible sur « www.inra.fr », visité le 9 Février 2019.

[12] Kouadio, J. 2012. Ochratoxine A en Côte d'Ivoire : moisissures ochratoxinogènes, exposition humaine et détoxification des aliments. Revue Ivoirienne des Sciences et Technologie (20) 87-103.

[13] Kouassi, C., Coulibaly, I., Coulibaly, B. \& Konate, I. 2018. Diagnosis and characteristics of street food consumption in a city with high population growth: case of Daloa (Côte d'Ivoire). International Journal of Science and Research 7 (6) :1129-1133.

[14] Mihajlovic, B., Dixon, B., Couture, H. \& Farber, J. 2013. Évaluation qualitative des risques microbiologiques que comportent les jus non pasteurisés de pomme et d'autres fruits. International Food Risk Analysis Journal 3(6): 1-22.

[15] Ndiaye, N., Dieng, M., Kane, A., Cisse, M., Montet, D. \& Toure, N.C. 2015. Diagnostic et caractérisation microbiologique des procédés artisanaux de fabrication de boissons et de concentrés d'Hibiscus sabdariffa L au Sénégal. Afrique Science 11(3) : 197-210.

[16] Tannons, J., Atoui, A., Khoury, A., Kantar, S., Chdid, N., Oswald, I., Puel, O. \& Lteif, F. 2015. Development of a Real-Time PCR assay for Penicillium expansum quantification and patulin estimation in apples. Food microbiology 50:28-37. 